\title{
Analysis of the current situation and development prospects of consumers' cooperation of Vologda region's rural areas
}

\author{
Marina Selina ${ }^{1, *}$, and Vladimir Selin ${ }^{2}$ \\ ${ }^{1}$ Vologda State Dairy Farming Academy, 160555 Vologda, Russian Federation \\ ${ }^{2}$ ART-RYBA LLC, 160014 Vologda, Russian Federation
}

\begin{abstract}
This study analyzed the current financial and economic state of consumers' cooperation of rural territories in Russia on the example of the Vologda region. The factors that discourage the consumers' cooperation organizations development were identified and substantiated. Also, the main problems arising on the way to the digital economy were presented on the example of consumers' cooperation organizations. An expert opinion on the changes' influence in the legislation of the Russian Federation on the social and economic activity of consumers' cooperation organizations was complied. Comparative analysis of break-even retail outlets under different taxation systems was performed. The forecast model of revenue from the consumers' cooperation organizations sales has been constructed. The research results are of practical importance for making competent managerial decisions in the field of support of consumers' cooperation organizations.
\end{abstract}

\section{Introduction}

Food security of the Russian Federation is one of the main directions of national security in the medium term, a factor in the preservation of statehood and sovereignty, an essential component of population policy and a prerequisite for the realization of such a strategic national priority as improving the quality of life of Russian citizens by guaranteeing high standards of life support [1].

In addition to food availability, it is necessary to consider aspects of its physical and economic accessibility to the population, as well as the criterion of food safety [2]. It is the considerations of ensuring social stability and security that lead all developed countries to regulate the situation in the food market, supporting the solvent demand of food buyers and supporting their agricultural producers [3].

As any other state, the socio-economic development of the Russian Federation is determined by the influence of a huge number of factors. Among them there were so-called "big challenges", which are not only dictated by external global circumstances, but also result from internal processes [4].

\footnotetext{
${ }^{*}$ Corresponding author: art-fish.smn@mail.ru
} 
In recent decades, the world is rapidly moving towards a new type of economy, the main formation tool of which is digital technologies [5].

Now, Russia is in dire need of effective mechanisms for launching regional economic growth. On the one hand, this need is caused by the stagnant growth in previous years, on the other - by the need to equalize the territories' development levels, between which the already huge gap is constantly increasing [6].

Historically, consumers' cooperation provided the need firstly for the rural population with food and other goods since the time of the USSR. Consumers' cooperation is not only trade, but also the production of current consumption goods, services, gathering and purchase of wild plants (berries, mushrooms), etc.

In fact, in the $1990 \mathrm{~s}$, consumers' cooperation was the main system of providing consumer goods for the districts of the Vologda region.

Since the beginning of the $2000 \mathrm{~s}$, private enterprises and entrepreneurs (sometimes on the basis of consumers' cooperations) began to actively develop, which compelled competition to district and urban consumers' communities, but healthy competition allowed more effective organizations to develop [7].

Starting from 2008-2009, the situation began to change when the outlets of some of the leading retail chains in Russia - Tander JSC (Magnit retail trade system) and" Pyaterochka" - appeared in the Vologda region. They occupied a dominant position in trade first in the cities, and then in the districts of the region. Low prices, wide assortment, low tax burden allowed retail to quickly displace most of consumers' cooperation from district centers of the region.

Table 1. Development indicators dynamics of consumers' cooperation of the Vologda region.

\begin{tabular}{|l|c|c|c|c|c|c|}
\hline \multicolumn{1}{|c|}{ Development indicators } & $\mathbf{2 0 1 3}$ & $\mathbf{2 0 1 4}$ & $\mathbf{2 0 1 5}$ & $\mathbf{2 0 1 6}$ & $\mathbf{2 0 1 7}$ & $\mathbf{2 0 1 8}$ \\
\hline $\begin{array}{l}\text { The rate of growth (decrease) of sales } \\
\text { revenue to the previous year, in \% }\end{array}$ & - & -4.06 & -7.62 & -7.25 & -13.56 & -9.50 \\
\hline $\begin{array}{l}\text { The amount of proceeds relative to } \\
\text { large enterprises with revenues of } \\
\text { over 200 million rubles, million rub. }\end{array}$ & 2279 & 2334 & 2342 & 2338 & 2194 & 2126 \\
\hline $\begin{array}{l}\text { Share of revenue relative to large } \\
\text { enterprises to the total, \% }\end{array}$ & 53.03 & 56.62 & 61.49 & 66.18 & 71.86 & 76.94 \\
\hline $\begin{array}{l}\text { Share of revenue of relatively small } \\
\text { enterprises to the total, in \% }\end{array}$ & 46.97 & 43.38 & 38.51 & 33.82 & 28.14 & 23.06 \\
\hline
\end{tabular}

There is negative dynamics in sales revenue (table 1), with chain indices showing a decrease in the indicator each year. The share of total enterprises turnover with revenues of less than 200 million per year decreases sharply - from $47.0 \%$ to $28.0 \%$. Accordingly, the revenue share of relatively stable and large enterprises with a turnover of more than 200 million rubles (and decreasing revenues by only $6.7 \%$ over the period) increases to $71.0 \%$ in 2018. When the UTII is cancelled, they fall under the general taxation system with a fold increase in the tax burden and deterioration of the financial condition. During the period under study, there was a tendency to decrease the turnover of small enterprises with their subsequent activity termination.

\section{Materials and methods}

The purpose of this study was to identify the problems of consumers' cooperation development of rural areas in the region, to propose possible ways of their solution, to assess the feasibility of cancelling the single tax on imputed income. The relevance of the study is determined by the strategic task of effective development of rural territories' consumers' cooperation organizations as a whole to ensure food security of regions and the Russian Federation as a whole. Consumers' cooperation was and still is playing an 
important role in the food security of the regional economy of the country. Especially for those territories that often have a shortage or lack of retails. Therefore, the importance of preserving - and at best, developing - this economic direction does not require much proof.

The evidence base is based on solution search of the following research tasks: 1) assessment of the current economic situation in consumers' cooperation; 2) designation of factors that impede economic activities of consumers' cooperation organizations; 3) comparative analysis of the economic effect of consumers' cooperation organizations through the lens of taxation. The results of this study have practical significance for public administration bodies as they allow to assess the effect of using a single tax on imputed income for subsequent decisions' adoption on the feasibility of its application. The organizations of the Vologda Regional Union of Consumers' Cooperations (hereinafter referred to as the Vologda Regional Consumers' Union) and the Regional Union of Consumers' Cooperatives (hereinafter referred to as Soyuzkoop). The study is based on open public data: data from the Federal Tax Service of Russia, data of management accounting of consumers' cooperation enterprises of the Vologda region. The results of requests to the Federal Tax Service of Russia and the Federal Service of State Statistics were used to analyze the pattern in the work. Research is based on information methods of data structuring. The study used scientific cognition techniques analysis, synthesis and econometric modelling based on time series; method of indicators' comparison and forecasting of the Vologda regional consumers' union was used to determine the effect of legislative changes' application.

\section{Results and discussion}

The negative situation with the development dynamics of consumers' cooperation organizations in the region is associated with the following factors. Having no social orientation and the main purpose of profit, uncontrollable admittance of federal trade networks created a situation that destroys consumers' cooperation organizations and local small and medium-sized enterprises. At the same time, there is a process of eliminating local producers that are deprived of sales markets and unable to make their way to the consumer in competition with federal retail networks. The second negative factor in the decline in the consumers' cooperation organizations activity volumes was the increased burden of "digital" services (table 2).

Table 2. Separate financial indicators for the group of "Soyuzkoop" consumers' cooperation companies of the Vologda region, million rub.

\begin{tabular}{|c|l|c|c|c|c|c|c|}
\hline It.No. & \multicolumn{1}{|c|}{ Indicator name } & 2015 & 2016 & 2017 & 2018 & 2019 & $\begin{array}{c}\text { Rate of } \\
\text { growth/contraction in } \\
\% \text { 2019 to 2015 }\end{array}$ \\
\hline $\mathbf{1}$ & Revenue & 1535 & 1514 & 1506 & 1474 & 1478 & 96.0 \\
\hline $\mathbf{2}$ & Financial result & 21.3 & 20.9 & 9.8 & -7.3 & -10.5 & -149.3 \\
\hline $\mathbf{3}$ & Taxes accrued & 36.6 & 39.7 & 44.7 & 46.9 & 46.5 & 127.1 \\
\hline $\mathbf{4}$ & Banking & 4.9 & 6.2 & 8.2 & 10.4 & 12.2 & 248.3 \\
\hline & incl. acquiring & 1.9 & 3.9 & 5.5 & 7.5 & 9.2 & 480.4 \\
\hline $\mathbf{5}$ & "Taxes" on digitalization & 0.12 & 4.3 & 6.5 & 5.4 & 6.6 & 5500 \\
\hline $\mathbf{5 . 1}$ & online registers & 0.1 & 3.1 & 3.9 & 2.1 & 3.0 & 3000 \\
\hline $\mathbf{5 . 2}$ & USAIS expenses & 0 & 1.2 & 1.9 & 2.0 & 1.7 & - \\
\hline $\mathbf{5 . 3}$ & Expenses on FSIS "Mercuriy" & 0 & 0.01 & 0.6 & 1.3 & 1.6 & - \\
\hline $\mathbf{5 . 4}$ & Costs for UT-11 & 0.03 & 0.02 & 0.1 & 0.04 & 0.24 & 873.4 \\
\hline $\mathbf{6}$ & utility costs, total & 38.7 & 43.3 & 48.4 & 49.0 & 50.6 & 130.7 \\
\hline & incl. electricity & 28.9 & 33.4 & 36.5 & 37.2 & 38.0 & 131.5 \\
\hline & sanitation & 0.3 & 0.4 & 0.6 & 0.6 & 1.2 & 400 \\
\hline
\end{tabular}


Note that with a decrease in revenue by $4 \%$, the taxes accrual increased by $27.1 \%$, which indicates an outpacing growth of the fiscal burden.

In 2019 , banking costs of organizations exceeded the aggregate loss by $16.2 \%$. Thus, it can be concluded that with adequate bank tariffs in 2019, consumers' cooperation could have reached a positive financial result. The size of tariffs for banking services leads to the fact that money flows to the financial sector from the real sector of the economy and do not find a way back, because on the one hand, the opportunities to get a loan for small business representatives are limited due to the reluctance of banking organizations to cooperate with such companies. On the other hand, it is not economically feasible, firstly, when using borrowed sources of financing to replenish current assets, it will further aggravate the financial situation of enterprises at high interest rates, and secondly, getting a loan for investment purposes is irrelevant since there are no potentially effective investment projects for consumers' cooperation organizations.

The main financial problems of enterprises are also related to the cost of digitalization. Costs for online cash registers, automation, unified state automated information system (EGAIS), federal state information system (FGIS) "Merkuriy" amount to 1.6 million rubles per year, or $15.2 \%$ of the resulting loss in 2019. "Digital" costs have increased 5.5 times over 5 years. These processes were accompanied by a decrease in labor productivity, since the labor costs of supporting "digitalization" require higher qualifications; with the failure of these systems, the labor process is delayed indefinitely.

Currently, new risks have arisen that can inflict irreparable damage to consumers' cooperation organizations. This refers to the cancellation of a special tax regime - a single tax on imputed income (UTI). We carried out a study, which included 13 selected retail outlets of small business organizations similar in size and assortment to consumer's cooperation organizations, and economic risks were assessed (table 3) in their transition from uniform tax on imputed income (UTII) to the general taxation system (GTS).

Table 2. Comparative analysis of break-even retail outlets under different taxation systems, rub.

\begin{tabular}{|l|c|c|c|c|}
\hline \multicolumn{1}{|c|}{ Indicators } & \multirow{2}{*}{ Fact (with UTII) } & \multicolumn{2}{c|}{$\begin{array}{c}\text { Fact } \\
\text { (with } \\
\text { GTS) }\end{array}$} & \multicolumn{2}{c|}{$\begin{array}{c}\text { Break-even point } \\
\text { calculation by revenue } \\
\text { (Forecast) }\end{array}$} \\
\cline { 3 - 5 } & & & with UTII & with GTS \\
\hline Sales revenues (average) & $\mathbf{7 4 1 ~ 0 3 0}$ & $\mathbf{7 4 1 ~ 0 3 0}$ & $\mathbf{5 4 0 ~ 3 2 5}$ & $\mathbf{6 3 1 ~ 6 7 3}$ \\
\hline Cost value of goods & 600025 & 600025 & 437510 & 511476 \\
\hline VAT reclaimed (by costs) & - & 2842 & - & 2842 \\
\hline VAT reclaimed (by goods) & - & 43634 & - & 37195 \\
\hline Costs by retail outlet & 102815 & 102815 & 102815 & 102815 \\
\hline VAT to accrual & - & 67360 & - & 57419 \\
\hline VAT payable & - & 20884 & - & 17382 \\
\hline Profit pre-tax & - & 17307 & - & 0 \\
\hline Income tax & - & 3461 & - & 0 \\
\hline Net profit (with GTS) /net income (with UTII) & $\mathbf{3 8 ~ 1 9 1}$ & $\mathbf{1 3 8 4 6}$ & $\mathbf{0}$ & $\mathbf{0}$ \\
\hline Total taxes & 5025 & 24345 & 5025 & 17382 \\
\hline Total taxes and payroll accruals & 21688 & 41008 & 21688 & 34045 \\
\hline
\end{tabular}

The calculation method included finding average revenue, costs, the ratio of incoming VAT and other indicators for three months (September, October, November 2019). Actual indicators when applying UTII were transferred to the terms of GTS, that is, VAT is considered and income tax is charged. With an estimated average revenue of 741,030 rubles per month, the tax increase will average to 4.85 times. The overall fiscal burden, which includes insurance fees, will rise 1.89 times.

Further, the minimum revenue under different taxation systems is calculated according to the method. When switching to GTS, the break-even threshold will rise by $17 \%$. 
According to these calculations and expert data, the forecast revenue model of the Vologda Regional Union of Consumers' Cooperations was constructed (Figure 1).

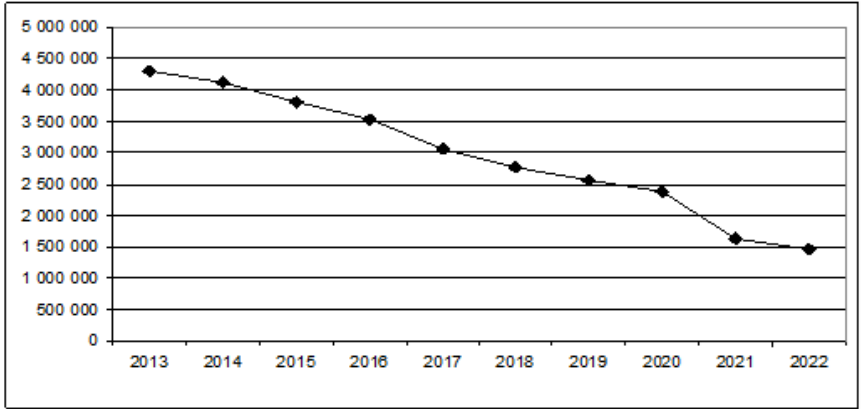

Fig. 1. Revenue forecast of the Vologda Regional Union of consumers' cooperation, thousand rubles.

\section{Conclusion}

In the current conditions, the rural territories consumers' cooperation organizations and representatives of small businesses are in a special group of economic risks, not possessing sufficient financial resources for bearing the costs of digital services. As a result, the share of small businesses in the economy will decrease and the strategic goal set in the national project "Small and medium-sized entrepreneurship - strategic target of increasing small entrepreneurship share to $32.5 \%$ of GDP by 2024" [8], will not be achieved.

In our opinion, it is necessary to pay attention to the development and support of the project "Real Vologda product", because promotion of the "Real Vologda product" brand is one of promising Vologda projects, which is of great importance in shaping the region's image as a whole as a territory capable of producing not only traditionally safe but also modern, high quality food products; it also creates prerequisites for more active use of the existing processing facilities available in the field of production facilities $[9,10,11]$.

Further independent studies should be carried out to assess the regulatory impact of UTII cancellation for small enterprises in the food and non-food segments with broad follow-up public discussion. In our view, the Federal Antimonopoly Service should assess the adequacy of commercial banks' tariffs on acquiring by comparing, among other, rates for federal retail networks and consumers' cooperations; check the pricing system for information technology companies' services.

\section{References}

1. V.M. Selin, Economic and Social Changes: Facts, Trends, Forecast, 6(42), 139 (2015)

2. A. N. Chekavinskiy, R. Yu. Selimenkov, Modeling of food security in the region, Economic and Social Changes: Facts, Trends, Forecast, 4, 226 (2014)

3. O.G. Moronova, A.P. Dorogovtsev, 1, 99 (2010)

4. V.S.Uskov, Economic and Social Changes: Facts, Trends, Forecast, 13(6), 134 (2020)

5. V.S. Uskov, Economic and Social Changes: Facts, Trends, Forecast, 12, 128 (2019)

6. E.V. Balatsky, N.A. Ekimova, Economic and Social Changes: Facts, Trends, Forecast, 13(3), 74 (2020)

7. T.G. Yureneva, O.I. Barinova, S.G. Golubeva, Towards Productive, Sustainable and Resilient Global Agriculture and Food Systems Conference proceedings, 1500 (2018) 
8. National project "Small and medium-sized entrepreneurship and support of private enterprisers' initiative", https://www.economy.gov.ru

9. O.N. Burgomistrova, AgroZoOtechnics, 4, 1 (2018)

10. O.A. Shikhova, M.N. Selina, O.I. Barinova, BIO Web of Conferences. International Scientific-Practical Conference "Agriculture and Food Security: Technology, Innovation, Markets, Human Resources" 27, 00031, 00157 (2020)

11. O.A. Shikhova, M.N. Selina, O.I. Barinova, MRA, 3, 57 (2020) 